\title{
6
}

\section{More regulated, more level? Assessing the impact of spending and donation caps on Australian State elections}

\author{
Jennifer Rayner
}

To level the playing field and stand up for a truly democratic electoral system in Australia ... it's time to cap election spending and political donations.

- Christine Milne ${ }^{1}$

It is acknowledged in both scholarly research and popular commentary that the Labor and Liberal parties enjoy a range of advantages over their minor party counterparts. In particular, these major parties possess financial, organisational and human resources that provide them with a distinct advantage during election campaigns and, it is often argued, skew the electoral playing field heavily in their favour. Consequently, calls to cap the amounts that political parties can spend and receive when campaigning for a federal election are a mainstay of Australian political discourse. The unconstrained way in which parties can raise and spend money has variously been referred to as

$1 \quad$ Press conference, 29 May 2013. 
'a risk for democracy and fairness', ${ }^{2}$ a source of 'unfair advantage' for the established major players ${ }^{3}$ and a 'corrupting influence' that links electoral success to the size of a party's advertising expenditure rather than the strength of its policies and arguments. ${ }^{4}$

Central to this debate is the analogy of the 'playing field' on which political parties - as electoral opponents - should ideally compete on an even footing. It is suggested that money in politics tilts the electoral playing field in favour of a small handful of actors, and that greater regulation and restriction of campaign financing (including caps on donations and spending) are therefore needed to level out this field again. Although this chapter acknowledges there are several normative propositions that underlie the notion of the level playing field, it does not engage in a debate about the appropriateness of this analogy. Instead, the fundamental question addressed in this chapter is: do spending and donation caps actually achieve their desired outcome of fostering more equal electoral competition or 'levelling the playing field' between political actors?

Proponents of these reforms rarely provide any specific evidence to back up their calls for change, and international research on this question offers a decidedly equivocal view. ${ }^{5}$ Taking this debate forward through original empirical research, the chapter assesses the impact of campaign finance caps in the Australian electoral context. In recent years, both New South Wales (NSW) and Queensland have introduced such caps for State elections, providing excellent contemporaneous case studies for exploring the impact of increased financial regulation on party behaviour. ${ }^{6}$

2 Brenton Holmes (2014) 'Money in Electoral Politics: No Small Risk for Democracy and Fairness', FlagPost: Information and Research from the Parliamentary Library, Canberra: Parliament of Australia, available at: aph.gov.au/About_Parliament/Parliamentary_Departments/ Parliamentary_Library/FlagPost/2014/April/MoneyInPolitics.

3 Marian Sawer (2013) 'The State of Australian Democracy', The Conversation, 3 September, available at: theconversation.com/election-2013-essays-the-state-of-australian-democracy-17530. 4 Lee Rhiannon (2011) Dissenting Report: Joint Standing Committee on Electoral Matters Inquiry into the Funding of Political Parties and Election Campaigns, Canberra: Parliament of Australia.

5 See, for example, Kevin Milligan and Marie Rekkas (2008) 'Campaign Spending Limits, Incumbent Spending, and Election Outcomes', The Canadian Journal of Economics 41(4): 1351-74; Ron Johnston and Charles Pattie (2008) 'Money and Votes: A New Zealand Example', Political Geography 27(1): 113-33.

6 See Table 1.2 in this volume for a comparison of characteristics of the State and Territory regulatory regimes and the dates of their introduction. 
Utilising published party disclosures on campaign donations and spending, the chapter begins by analysing debates concerning the significance of money in elections. It then establishes how much of a financial disparity existed between big and small parties before the reforms were introduced and examines what, if anything, the caps have done to close that gap. The focus here is the system of private funding of parties, which, as Graeme Orr highlights in his chapter, sits alongside public funding in Australia. The analysis shows that while the introduction of donations and expenditure caps has created greater financial parity between the two major political parties, it has done little to reduce the discrepancy between major and minor parties' financial positions.

\section{The significance of money in politics}

Before analysing the two Australian case studies, it is worth unpacking some of the ideas that underpin calls for campaign finance reform and the idea of the level playing field. Although the primary focus of the chapter is on the intersection of money and electoral competition, there are numerous other reasons for regulating and restricting political finance. These include curbing undue influence by outside groups and minimising the volume of advertising and the associated focus on media presentation over policy development and community engagement.

In terms of electoral competition, the most significant idea underpinning calls for caps is that money provides a competitive advantage when campaigning for elected office. If money did not provide such an advantage, it would not matter if some parties earn and spend more of it than others. The question of just how much money matters - and whom it advantages the most-has frequently been explored in the international literature on elections and campaigning. The broad consensus is that although the party or candidate with the deepest pockets does not always win, there is generally a positive relationship between spending and electoral performance. For example, research by Johnston and colleagues over two decades in the United Kingdom consistently found that-net of other factors-increased spending translated to increased vote 
share on election day. ${ }^{7}$ Research in countries as diverse as Canada, ${ }^{8}$ Ireland, ${ }^{9} \mathrm{Korea}^{10}$ and the United States ${ }^{11}$ has reached similar, although not always so consistent, conclusions. In Australia, the more limited reporting requirements for campaign spending have made it difficult to replicate this kind of detailed empirical research. However, in the 1990s, Forrest conducted a series of studies that drew on NSW data to explore the relationship between spending and outcomes at elections in that State. He concluded that money appeared to deliver similar electoral benefits to those seen internationally, although the size of that benefit varied in connection with the level of political volatility at any given election. ${ }^{12}$

Interviews with over 60 Australian major and minor party representatives conducted as part of my doctoral research revealed a strong consensus that money matters a great deal when it comes to designing and delivering election campaigns. ${ }^{13}$ Interviewees reported that money is a crucial determinant of how widely, frequently and effectively a party can convey its campaign messages to voters, how many seats it can run in, the strength of on-the-ground campaigning

7 Ron Johnston and Charles Pattie (1997) 'Where's the Difference? Decomposing the Impact of Local Election Campaigns in Great Britain', Electoral Studies 16: 165-74; Charles Pattie, Ron Johnston and Ed Fieldhouse (1995) 'Winning the Local Vote: The Effectiveness of Constituency Campaign Spending in Great Britain, 1983-1992', American Political Science Review 89: 969-83; Ron Johnston (1987) Money and Votes: Constituency Campaign Spending and Election Results, London: Croom Helm.

$8 \quad$ Ken Carty and Munroe Eagles (1999) 'Do Local Campaigns Matter? Campaign Spending, the Local Canvass and Party Support in Canada', Electoral Studies 18: 69-87; Munroe Eagles (1993) 'Money and Votes in Canada: Campaign Spending and Parliamentary Election Outcomes, 1984-1988', Canadian Public Policy 19: 432-49.

$9 \quad$ Ken Benoit and Michael Marsh (2003) 'For a Few Euros More: Campaign Spending Effects in the Irish Local Elections of 1999', Party Politics 9(5): 561-82.

10 Myungsoon Shin, Youngjae Jin, Donald Gross and Kihong Eom (2005) 'Money Matters in Party-centred Politics: Campaign Spending in Korean Congressional Elections', Electoral Studies 24(1): 85-101.

11 Robert Erikson and Thomas Palfrey (2000) 'Equilibria in Campaign Spending Games: Theory and Data', American Political Science Review 94: 595-609; Alan Gerber (1998) 'Estimating the Effect of Campaign Spending on Senate Election Outcomes Using Instrumental Variables', American Political Science Review 92(2): 401-11; Donald Green and Johnathan Krasno (1990) 'Rebuttal to Jacobson's "New Evidence for Old Arguments"', American Journal of Political Science 34: 363-72.

12 James Forrest, Ron Johnston and Charles Pattie (1999) 'The Effectiveness of Constituency Campaign Spending in Australian State Elections during Times of Electoral Volatility: The New South Wales Case, 1988-95', Environment and Planning 31(1999): 1119-28; James Forrest (1997) 'The Effects of Local Campaign Spending on the Geography of the Flow-of-the-Vote at the 1991 New South Wales State Election', Australian Geographer 28(2): 229-40.

13 Jennifer Rayner (2014) Beyond Winning: Party Goals and Campaign Strategy in Australian Elections, Doctoral thesis, Canberra: The Australian National University. 
within these and how much professional help it can access to guide its strategising and implementation. Furthermore, money was a frequently cited factor when these representatives sought to explain why their parties had or had not carried out particular campaign activities. ${ }^{14}$ Importantly, however, many of the interviewees reflected that a sizeable budget is generally not sufficient to get an underperforming candidate elected or make up for a lack of resonant message. So while parties do not see money as everything, they clearly see it as a very important factor driving the delivery of their campaigns.

\section{Disparities in campaign budgets}

A second idea underlying the discussion about caps and the level playing field is that there is an asymmetry to campaign budgets that provides some Australian parties with an advantage over others. To what extent is this really the case?

Examining the dollar amounts declared for the past three federal election years indicates that there are major disparities in the amounts earned and spent by Australian parties.

This gulf in party budgets would not come as a surprise to most observers of politics. Importantly, however, Table 6.1 indicates that there is not just a division between wealthy major parties and poor minor ones. Rather, Australia's system is better conceptualised as a three-tiered one, with the Labor and Liberal parties representing a top tier in which budgets are counted in tens of millions. The entry of the Palmer United Party (PUP) into the federal political arena in 2013, backed by billionaire Clive Palmer, was a significant development. Formed just six months before the federal election, PUP was able to field candidates in all 150 House of Representatives seats and to raise and spend as much money as the established major parties. Beneath Labor, Liberal and PUP sit parties such as The Greens and The Nationals, with budgets that hover between \$2 million and $\$ 5$ million. Newer parties such as Family First also appear to be progressing rapidly towards this bracket. Finally, far beneath these two tiers sit the rest of the minor parties, with budgets that are counted in hundreds of thousands of dollars, and sometimes even less. 
PARTY RULES?

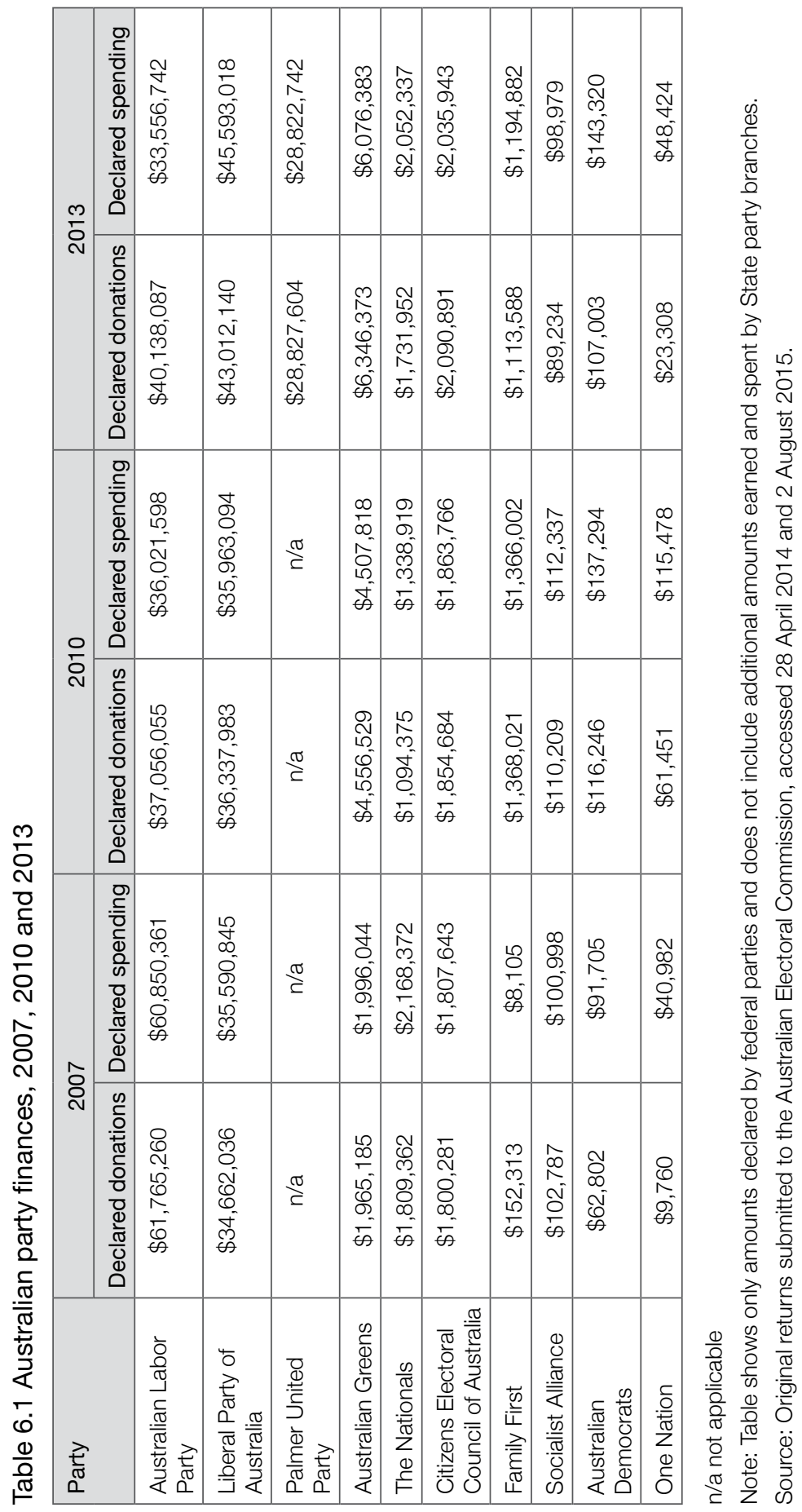


If we consider the figures for the three Australian States that require detailed campaign reporting, similar disparities are apparent in terms of party finances.

Table 6.2 Australian State party finances, State elections, 2011-13

\begin{tabular}{|c|c|c|c|}
\hline Party & Election & Declared donations & Declared spending \\
\hline $\begin{array}{l}\text { Liberal Party } \\
\text { of Australia }\end{array}$ & $\begin{array}{l}\text { Western Australia } \\
2013\end{array}$ & $\$ 11,381,300^{*}$ & $\$ 5,141,459$ \\
\hline $\begin{array}{l}\text { Australian Labor } \\
\text { Party }\end{array}$ & $\begin{array}{l}\text { Western Australia } \\
2013\end{array}$ & $\$ 5,819,500^{*}$ & $\$ 2,756,512$ \\
\hline The Greens & $\begin{array}{l}\text { Western Australia } \\
2013\end{array}$ & $\$ 1,305,589^{*}$ & $\$ 446,090$ \\
\hline The Nationals & $\begin{array}{l}\text { Western Australia } \\
2013\end{array}$ & $\$ 1,533,867^{*}$ & $\$ 323,692$ \\
\hline $\begin{array}{l}\text { Australian } \\
\text { Christians }\end{array}$ & $\begin{array}{l}\text { Western Australia } \\
2013\end{array}$ & $\$ 466,217^{\star}$ & $\$ 60,460$ \\
\hline $\begin{array}{l}\text { Liberal National } \\
\text { Party }\end{array}$ & Queensland 2012 & $\$ 16,860,534$ & $\$ 7,154,900$ \\
\hline $\begin{array}{l}\text { Australian Labor } \\
\text { Party }\end{array}$ & Queensland 2012 & $\$ 10,753,968$ & $\$ 7,118,139$ \\
\hline $\begin{array}{l}\text { Katter's Australian } \\
\text { Party }\end{array}$ & Queensland 2012 & $\$ 2,098,379$ & $\$ 1,180,719$ \\
\hline The Greens & Queensland 2012 & $\$ 484,464$ & $\$ 748,054$ \\
\hline One Nation & Queensland 2012 & $\$ 29,772$ & $\$ 40,637$ \\
\hline $\begin{array}{l}\text { Liberal Party } \\
\text { of Australia }\end{array}$ & $\begin{array}{l}\text { New South Wales } \\
2011\end{array}$ & $\$ 9,824,074$ & $\$ 11,376,435$ \\
\hline $\begin{array}{l}\text { Australian Labor } \\
\text { Party }\end{array}$ & $\begin{array}{l}\text { New South Wales } \\
2011\end{array}$ & $\$ 3,760,765$ & $\$ 11,105,679$ \\
\hline The Nationals & $\begin{array}{l}\text { New South Wales } \\
2011\end{array}$ & $\$ 2,311,510$ & $\$ 2,993,694$ \\
\hline The Greens & $\begin{array}{l}\text { New South Wales } \\
2011\end{array}$ & $\$ 339,040$ & $\$ 1,686,502$ \\
\hline $\begin{array}{l}\text { Christian } \\
\text { Democratic Party }\end{array}$ & $\begin{array}{l}\text { New South Wales } \\
2011\end{array}$ & $\$ 504,540$ & $\$ 308,477$ \\
\hline Family First & $\begin{array}{l}\text { New South Wales } \\
2011\end{array}$ & $\$ 25,687$ & $\$ 37,965$ \\
\hline Socialist Alliance & $\begin{array}{l}\text { New South Wales } \\
2011\end{array}$ & $\$ 22,221$ & $\$ 9,662$ \\
\hline
\end{tabular}

* Includes donations made in the reporting period encompassing the 2013 federal election. Sources: Original campaign returns submitted to the WA Electoral Commission, Electoral Commission Queensland and NSW Election Funding Authority, accessed 20 January 2014. 
The three-tiered division of wealth observed at the federal level also appears to be in place within Australia's State parties, although the overall scale of spending is smaller. So if money provides the kind of electoral advantage that international and local research suggests it does, it is clear from these figures that the major parties enjoy a considerable advantage over all other political contenders. Only a political party backed by considerable personal wealth, such as PUP, can rival the major parties in terms of fundraising and spending. Importantly, however, we can see that larger minor parties such as The Greens and The Nationals that have a history of parliamentary representation also enjoy a distinct advantage over most other parties entering the electoral arena.

\section{A more level playing field for whom?}

Another issue often unaddressed in the discussion about donation and spending caps is which political actors are actually supposed to benefit from the levelling that these reforms initiate. Much of the international literature on campaign financing focuses on inequalities between incumbents and challengers, because research in contexts such as the United States and Canada has consistently found that incumbents enjoy a financial — and therefore electoral — advantage. ${ }^{15}$ However, in Australia's party-dominated system, incumbency does not convey the same advantages in and of itself, because campaign funds are primarily controlled by party head office. Popular incumbents may raise some of their own money and enjoy non-financial advantages such as higher public visibility, ${ }^{16}$ but the competition in terms of spending and donations primarily happens at the party level.

15 See, for example, Jamie Carson, Erik Engstrom and Jason Roberts (2007) 'Candidate Quality, Personal Vote and the Incumbency Advantage in Congress', American Political Science Review 101(2): 289-301; Stephen Ansolabehere and James Snyder (2002) 'The Incumbency Advantage in US Elections: An Analysis of State and Federal Offices, 1942-2000', Election Law Journal 1(3): 315-38; Brian Gaines (1998) 'The Impersonal Vote? Constituency Service and Incumbency Advantage in British Elections, 1950-92', Legislative Studies Quarterly 23(2): 167-95; Gary King (1991) 'Constituency Service and Incumbency Advantage', British Journal of Political Science 21(1): 119-28.

16 Markus Prior (2006) 'The Incumbent in the Living Room: The Rise of Television and the Incumbency Advantage in US House Elections', Journal of Politics 68(3): 657-73. 
In that case, are we concerned about equalising the contest between the two major parties, such that we end the supposed 'arms race' of campaign spending? Or are we interested in levelling the field between major and minor parties, such that The Greens, Family First and other non-governing parties can compete more effectively against Labor and the Liberals?

In introducing the NSW legislation capping spending and donations in 2010, then Premier Kristina Keneally stated:

These reforms are ... directed at reducing the advantages of money in dominating political debate. They provide for a more level playing field for candidates seeking election, as well as for third parties who wish to participate in political debate. These reforms are about putting a limit on the political arms race, under which those with the most money have the loudest voice and can simply drown out the voices of all others. The reforms will help to give voters a better opportunity to be fully and fairly informed of the policies of all political parties, candidates and interested third parties. ${ }^{17}$

Similarly, when tabling Queensland's Electoral Reform and Accountability Amendment Bill in 2011, then Attorney-General Paul Lucas said: 'The bill will introduce a cap on donations for use in state campaigns to ensure equitable access to the political process for all participants. ${ }^{18}$

These statements suggest that the goal of Australia's two existing schemes is to create a playing field that is even for all who choose to enter it. This is clearly an unrealistic ambition, given the major disparities among Australian parties in terms of both their capacity to raise money and their broader institutional, knowledge and organisational resources. But nor is it necessarily desirable that niche or special interest parties should compete on a level footing with parties of government with substantial public support when campaigning in elections.

17 Kristina Keneally (2010) 'Second Reading Speech', Election Funding and Disclosures Amendment Bill 2010, 28 October. Emphasis added.

18 Paul Lucas (2011) 'Second Reading Speech', Electoral Reform and Accountability Amendment Bill 2011, 7 April. Emphasis added. 
Instead, I would simply suggest that when seeking to determine whether spending and donation caps 'work', it would be setting the bar too high to expect them to create a completely level playing field for all political parties. In the following discussion, then, the benchmark for success will be the extent to which the NSW and Queensland caps have narrowed the financial gulf between major and minor parties, rather than their capacity to close this altogether.

\section{The Australian experience}

Having discussed why capping donations and spending is seen as a way to level the electoral playing field, and having identified how we might determine the success or failure of such caps, we can now turn our attention to the two Australian case studies. The following section briefly outlines the key features of the NSW and Queensland schemes, and then explores what impact their introduction has had on party budgets.

Table 6.3 summarises the relevant restrictions on campaign donations and spending that were introduced in NSW in 2010 and Queensland in 2011. Norton, as well as Tham and Anderson, provide more in-depth discussions of the legal and definitional nuances of these laws, as well as the context of their introduction. ${ }^{19}$ For the purpose of this discussion, I am primarily concerned with the headline figures regulating the amounts that parties and candidates may receive and spend. As noted at the beginning of this chapter, the legislative changes introduced in 2010 and 2011 - and their consequent impact on political donations and expenditure in the 2011 (NSW) and 2012 (Queensland) State elections - have specifically been chosen because of the unique contemporaneous and comparable data that reform period provides. The 2011 and 2012 State elections and the legislative regimes under which they were fought therefore offer a rare and valuable window through which to examine the impact of caps across two different States.

19 Andrew Norton (2011) Democracy and Money: The Dangers of Campaign Finance Reform, CIS Policy Monograph 119, Sydney: Centre for Independent Studies; Joo-Cheong Tham and Malcolm Anderson (2011) How Effective are the New South Wales Election Spending Limits in Preventing Election 'Arms Races'? A Preliminary Inquiry, Melbourne: Democratic Audit of Australia. 
Table 6.3 NSW and Queensland caps introduced in 2010 and 2011

\begin{tabular}{|c|c|c|}
\hline & New South Wales & Queensland \\
\hline Party spending allowed & $\begin{array}{l}\$ 100,000 \times \text { number of Legislative } \\
\text { Assembly seats contested- } \\
\text { parties contesting more than } \\
10 \text { seats } \\
\$ 50,000 \text { cap also applies within } \\
\text { this for electoral communication } \\
\text { in any single electorate } \\
\$ 1,050,000-\text { parties running for } \\
\text { the Legislative Council and } 10 \text { or } \\
\text { fewer Legislative Assembly seats }\end{array}$ & $\begin{array}{l}\$ 80,000 \times \text { number of } \\
\text { electorates contested }\end{array}$ \\
\hline $\begin{array}{l}\text { Candidate spending } \\
\text { allowed }\end{array}$ & $\$ 100,000$ - additional to party cap & $\begin{array}{l}\$ 50,000-\text { additional to } \\
\text { party cap }\end{array}$ \\
\hline $\begin{array}{l}\text { Third-party spending } \\
\text { allowed }\end{array}$ & $\$ 1,050,000$ & $\begin{array}{l}\$ 500,000-\text { subject to } \\
\$ 75,000 \text { cap in any single } \\
\text { electorate }\end{array}$ \\
\hline $\begin{array}{l}\text { Maximum donation } \\
\text { allowed" }\end{array}$ & $\begin{array}{l}\$ 5,000 \text { for a registered party } \\
\text { or group } \\
\$ 2,000 \text { for a sitting MP, candidate } \\
\text { or third-party campaigner } \\
\$ 2,000 \text { for a party that is not } \\
\text { registered }\end{array}$ & $\begin{array}{l}\$ 5,000 \text { for a registered } \\
\text { party or group } \\
\$ 2,000 \text { for a sitting MP, } \\
\text { candidate or third-party } \\
\text { campaigner }\end{array}$ \\
\hline Reporting threshold & $\$ 1,000$ & $\$ 1,000$ \\
\hline Restricted donors & $\begin{array}{l}\text { Donations from property } \\
\text { developers, gambling and liquor } \\
\text { industry businesses and tobacco } \\
\text { industry businesses are prohibited }\end{array}$ & None \\
\hline
\end{tabular}

\# Donation caps apply to the receiving party rather than the donor. That is, a donor may donate more than these amounts and it is up to the receiving party to either return the funds or place them in a separate account for other purposes (for example, a federal campaign account).

Notes: Caps applying for 2011 State election-amounts are indexed to inflation and increase on 1 July each year. Caps applying for the 2012 State election-amounts are indexed to inflation and increase on 1 July each year.

Sources: NSW Election Funding Authority (2014) Caps on Political Donations, Sydney: Election Funding Authority; Electoral Commission Queensland (ECQ) (2014) Funding and Disclosure: Queensland State, Brisbane: ECQ.

While the NSW scheme remains largely in place (pending reforms subsequent to the Premier's Expert Panel on Political Finance, instigated in light of campaign financing irregularities revealed by 
the Independent Commission Against Corruption), ${ }^{20}$ the Newman Government scrapped Queensland's caps in 2013 and brought that State back into line with the federal campaign financing laws (see Graeme Orr, this volume). ${ }^{21}$ In 2015 a new Labor Government brought the threshold for disclosure of donations back down to $\$ 1,000$, but to date (October 2016) has not restored donation or expenditure caps.

As Table 6.3 indicates, the two schemes operated along broadly similar lines, although there are some important differences. Each set a maximum amount that parties may spend per electorate (indexed annually), adding up to an overall cap for spending across the State. Each also capped the total amount that parties and candidates may receive from any single donor and set a reasonably low threshold for disclosing these donations. ${ }^{22}$ Importantly, however, the two schemes differed in how they managed spending within any individual electorate. In Queensland at the 2012 State election, parties could spend up to the $\$ 80,000$ cap in any single seat. In NSW, however, an additional cap of $\$ 50,000$ applied for materials promoting an individual candidate within any single seat, which meant that the parties had to allocate the other half of their $\$ 100,000$ cap to Statewide campaigning. Furthermore, the Queensland scheme allowed candidates to spend a further $\$ 50,000$ on top of their party's general spending, while the NSW scheme was more generous in setting a $\$ 100,000$ additional cap for candidates. The net result of these rules is that for the 2011 NSW State election, the most a party and candidate combined could spend

20 Kerry Schott, Andrew Tink and John Watkins (2014) Political Donations Final Report. Volumes 1 and 2, Sydney: NSW Department of Premier and Cabinet, available at: dpc.nsw.gov. au/announcements/panel_of_experts_-_political_donations; Mike Baird (2014) 'Statement: ICAC', Media statement, 28 April, available at: members.nsw.liberal.org.au/news/state-news/ mike-baird-statement-icac; John Robertson (2014) 'NSW Labor Calls for an End to Campaign Donations to Restore Confidence in Politics and Government', Media statement, 5 May.

21 The Queensland Parliament passed the Electoral Reform Amendment Bill 2013 on 22 May 2014. In addition to scrapping spending and donation caps, the Bill also introduced Australia's first voter identification laws, requiring Queensland voters to provide one of several forms of photographic and non-photographic identification when voting in State elections. The Bill also increased the threshold for parties receiving public funding, meaning that parties must now earn 6 per cent of first-preference votes before being eligible to receive reimbursement for their campaign expenses. The Queensland Opposition and community groups vigorously opposed all of these changes on the grounds that they would diminish transparency, disenfranchise voters and further entrench the electoral dominance of the major parties. However, with a 69-seat majority in Queensland's unicameral Parliament, there was little to prevent the Liberal National Party (LNP) Government from passing the Bill unamended.

22 By comparison, the current (October 2016) federal disclosure threshold is $\$ 13,200$. 
in any single electorate was $\$ 150,000$, while in Queensland in 2012 the maximum was $\$ 130,000$. These figures have since increased in line with indexation arrangements established in the legislation.

\section{Case study 1: Queensland}

Turning our attention first to Queensland as the more recent of the two schemes, Figure 6.1 shows the campaign spending for the parties that contested all three of the State elections between 2006 and 2012. ${ }^{23}$ For the 2006 and 2009 elections, there were no restrictions on the amount that parties could spend. The spending caps discussed in Table 6.3 then came into effect in 2011 and applied for the duration of the 2012 election campaign.

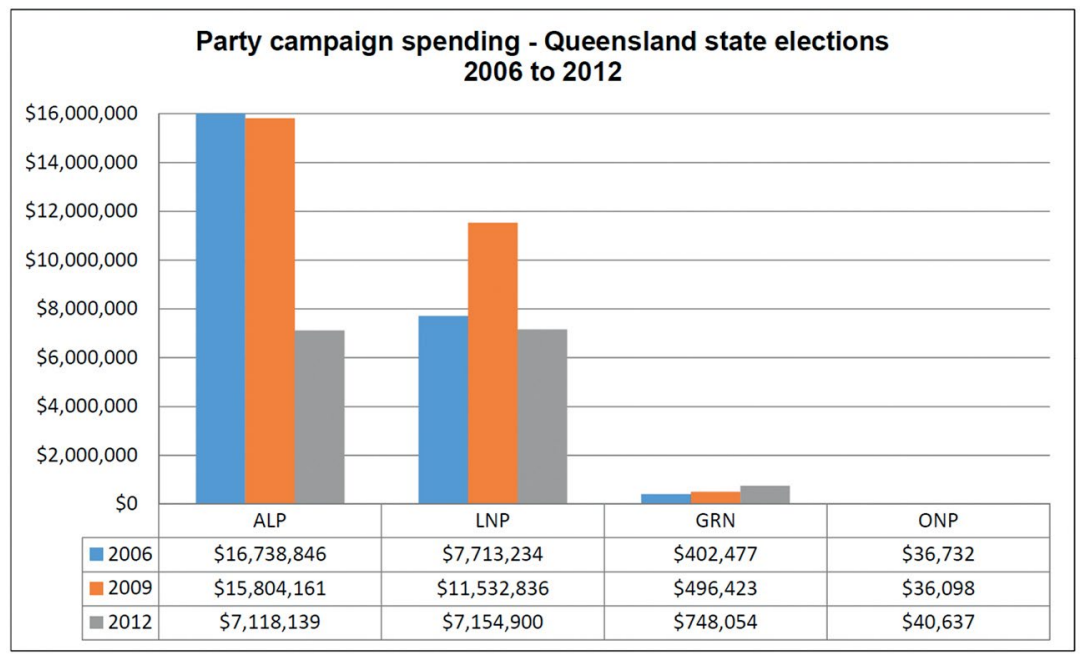

Figure 6.1 Queensland campaign spending, 2006-12

Sources: Spending figures for 2009 and 2012 calculated from original returns submitted to Electoral Commission Queensland; spending figures for 2006 calculated from original returns submitted to the Australian Electoral Commission.

Note: ALP = Australian Labor Party; LNP = Liberal National Party; GRN = The Greens; ONP = One Nation .

23 The Liberal and National parties contested the 2006 election as separate entities, but formally merged to form the Liberal National Party before the 2009 election. For the sake of consistency, the 2006 LNP figure is an aggregate of the individual Liberal and National parties' spending. 
What is immediately striking from the data in Figure 6.1 is how dramatically major party spending has diverged over the past three elections, as the Australian Labor Party (ALP) significantly outspent the Liberal National Party (LNP) at each of the two elections before the caps were introduced. The 'arms race' thesis of campaign spending contends that major party budgets should generally mirror each other and increase with each electoral contest, but recent research by Anderson and Tham suggests that the kind of variance observed here may actually be more common. They point out that parties in and out of government have different capacities to attract donor funds and also differ in their incentives to spend up big depending on whether the election is likely to be closely fought or very one-sided. This leads to considerable variation in spending between parties from election to election. ${ }^{24}$

For the 2012 election, the maximum allowable spend for a party running candidates in all 89 Queensland electorates was $\$ 7.12$ million. The fact that both the ALP and the LNP spent this amount almost to the dollar (despite a past history of spending more) would appear to indicate that the caps had a constraining effect on their spending. This observation is strengthened if we compare the amount the parties spent with the amount they received in donations; this information is presented as two separate figures because the difference between the major and minor parties is so great as to make graphing on a single scale difficult.

Figures 6.2 and 6.3 indicate that prior to the introduction of the caps, Queensland's major parties spent approximately the same amount as they received in donations, while the minor parties fluctuated between spending substantially more and substantially less than they received. However, after the introduction of the caps, no party could spend more than \$7.1 million regardless of how much money it had accumulated. Because of this, we see a larger gap between the amounts the ALP and the LNP received and the amounts they spent: \$3.6 million in Labor's case and $\$ 9.7$ million for the LNP. Importantly, too, we see that despite the LNP receiving over $\$ 6$ million more in donations than the ALP, that party spent just $\$ 36,000$ more on its election campaign. Given the close relationship between spending and donations at the previous

24 Malcolm Anderson and Joo-Cheong Tham (2014) 'Dynamics of Electoral Expenditure and the "Arms Race" Thesis: The Case of New South Wales', Australian Journal of Political Science 49(1): 84-101. 
two elections, it seems likely that this spending gap would have been significantly larger if the LNP had been free to spend more of the money it received in donations. For the two minor parties, we see no particular change after the introduction of the caps, beyond noting that the gap between donations received and amount spent increased in the opposite direction-dramatically so in the case of The Greens.

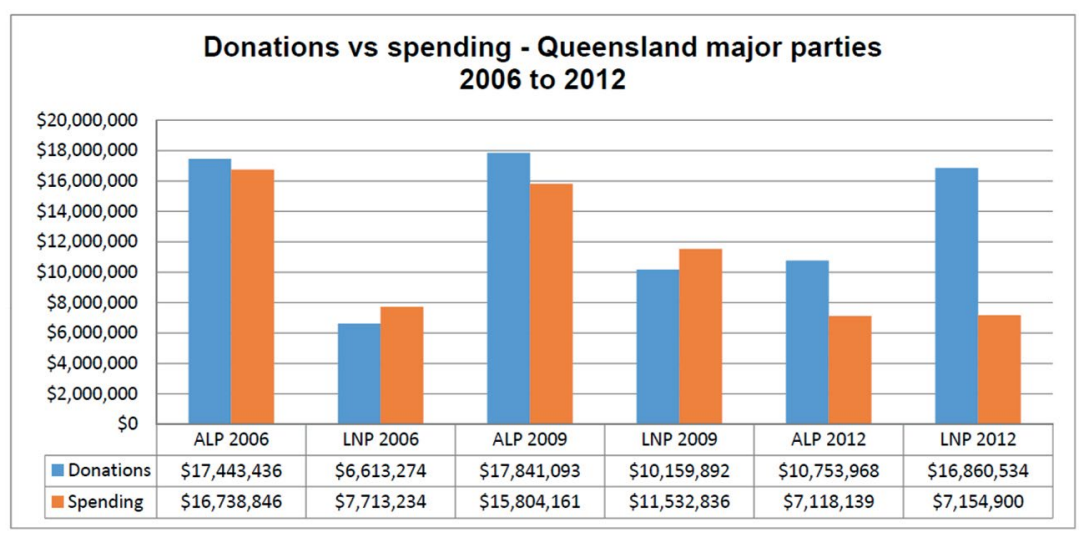

Figure 6.2 Queensland major party donations relative to spending, 2006-12

Sources: Spending and donation figures for 2009 and 2012 calculated from original returns submitted to Electoral Commission Queensland; spending and donation figures for 2006 calculated from original returns submitted to the Australian Electoral Commission.

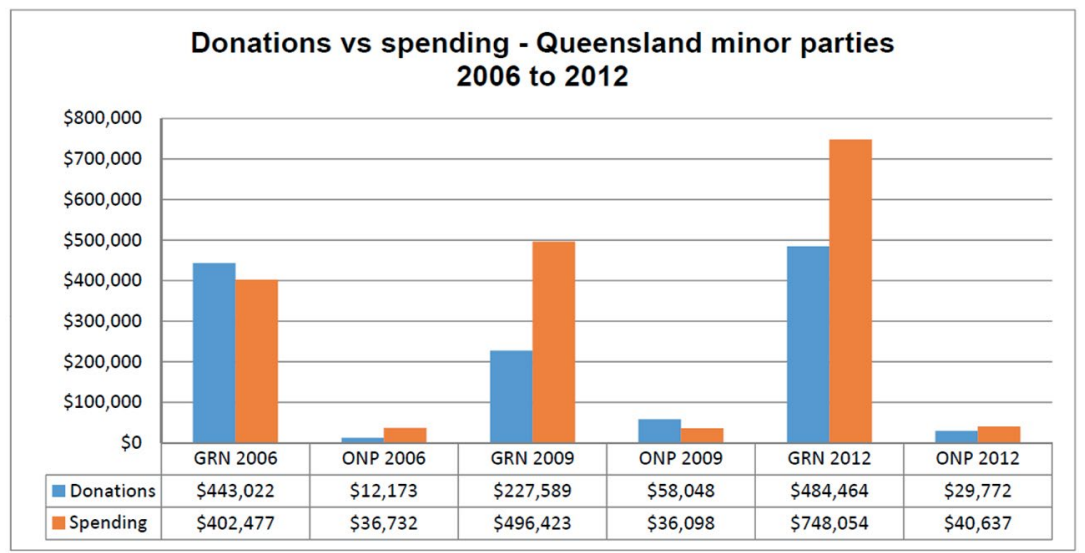

Figure 6.3 Queensland minor party donations relative to spending, 2006-12

Sources: Spending and donation figures for 2009 and 2012 calculated from original returns submitted to Electoral Commission Queensland; spending and donation figures for 2006 calculated from original returns submitted to the Australian Electoral Commission. 
To give a clearer sense of these trends in constant terms, Table 6.4 details the donations and money spent per enrolled voter in each of these three election years. Anderson and Tham opted to adjust all dollar figures to 2011 terms in their analysis, ${ }^{25}$ but since we are primarily interested in the relationship between party budgets and the capacity to campaign effectively, the amounts spent and received per voter make for a more valuable point of comparison here.

Table 6.4 Queensland party funds: Dollars per voter

\begin{tabular}{|l|c|c|c|c|c|c|}
\hline & \multicolumn{2}{|c|}{2006} & \multicolumn{2}{c|}{2009} & \multicolumn{2}{c|}{2012} \\
\hline Size of roll & \multicolumn{2}{|c|}{$2,484,479$} & \multicolumn{2}{c|}{$2,660,940$} & \multicolumn{2}{c|}{$2,746,844$} \\
\hline & Received & Spent & Received & Spent & Received & Spent \\
\hline Australian Labor Party & $\$ 7.020$ & $\$ 6.730$ & $\$ 6.700$ & $\$ 5.940$ & $\$ 3.910$ & $\$ 2.590$ \\
\hline Liberal National Party & $\$ 2.660$ & $\$ 3.100$ & $\$ 3.810$ & $\$ 4.330$ & $\$ 6.130$ & $\$ 2.600$ \\
\hline The Greens & $\$ 0.180$ & $\$ 0.160$ & $\$ 0.080$ & $\$ 0.190$ & $\$ 0.180$ & $\$ 0.270$ \\
\hline One Nation & $\$ 0.004$ & $\$ 0.014$ & $\$ 0.021$ & $\$ 0.013$ & $\$ 0.010$ & $\$ 0.014$ \\
\hline
\end{tabular}

Sources: Figures for 2009 and 2012 calculated from original returns submitted to Electoral Commission Queensland; figures for 2006 calculated from original returns submitted to the Australian Electoral Commission.

Three things are evident from the data in Table 6.4. First, the introduction of caps appears to have significantly reduced financial disparities between the two major parties in Queensland - at least on the spending side. The ALP and the LNP went from spending vastly different amounts on their campaigns to having budgets that were almost identical, as is evident from their respective spending per voter. The caps do not appear to have had the same impact on donations, as the LNP received one-and-a-half times the amount of money donated to the ALP even with restrictions on how much any one person or company could donate. However, this disparity in donations was ultimately of little benefit to the LNP, as the party was prohibited from spending it on the state campaign. This is in contrast with the previous two elections, where the ALP received significantly more in donations and was therefore able to spend far more on its re-election efforts.

Second, the introduction of caps has somewhat narrowed the financial gulf between the two major parties and their minor counterparts, but again only on the spending side. Table 6.5 illustrates this trend by detailing the money received and spent by the major parties for every $\$ 1$ of minor party funding. 
Table 6.5 Ratios of major and minor party finances: Queensland*

\begin{tabular}{|l|c|c|c|c|c|c|c|c|}
\hline & \multicolumn{3}{|c|}{2009} & \multicolumn{3}{c|}{2012} \\
\hline & \multicolumn{2}{|c|}{ Donations } & \multicolumn{2}{c|}{ Spending } & Donations & \multicolumn{2}{c|}{ Spending } \\
\hline & ALP & LNP & ALP & LNP & ALP & LNP & ALP & LNP \\
\hline The Greens & $78: 1$ & $44: 1$ & $31: 1$ & $23: 1$ & $22: 1$ & $39: 1$ & $9: 1$ & $9.5: 1$ \\
\hline One Nation & $307: 1$ & $175: 1$ & $437: 1$ & $319: 1$ & $361: 1$ & $566: 1$ & $175: 1$ & $176: 1$ \\
\hline
\end{tabular}

* Ratio of dollars received and spent by the major parties relative to every dollar of minor party funding (all minor parties aggregated).

Interestingly, the spending ratio of The Greens to One Nation (ONP) dollars actually increased between 2009 and 2012, at 13:1 and 18:1, respectively. However, this appears to have had little to do with the introduction of the caps and more to do with the fact that The Greens' campaign budget increased significantly while One Nation's remained almost static. Again, the fact that the major parties received many millions of dollars more in donations than the minor parties was ultimately of little benefit at the 2012 election, as both were prohibited from spending more than $\$ 7.12$ million regardless of how much money they had accumulated.

The third point evident from these data is that minor parties do not spend or receive anything like the amount of money that major parties do, regardless of what campaign finance rules are in place. While the ratio of minor to major party spending fell in 2012, The Greens were still spending just 18 cents per voter compared with approximately $\$ 2.60$ each for the two major parties, while One Nation spent slightly more than 1 cent per voter. ${ }^{26}$ As a consequence, the volume, reach and professionalism of their campaigns varied significantly. ${ }^{27}$ Interviews with representatives of both minor parties suggest that the caps were of little consequence to them, as they rarely came within distance of hitting them. For example, The Greens reportedly reached the $\$ 80,000$ party cap in just one seat, Mount Coot-tha, while One Nation's single largest spend was just under $\$ 30,000$, in the seat of Beaudesert. Importantly, however, The Greens were still outspent in Mount Coot-tha, as the ALP's sitting Member of Parliament (MP), Treasurer Andrew Fraser, was able to spend a further $\$ 44,847$ from

26 The One Nation dollar-per-voter figure is somewhat less comparable because the party did not run candidates in all seats.

27 Rayner, Beyond Winning. 
his individual cap on top of his party's $\$ 80,000$ cap. Similarly, LNP candidate Saxon Rice spent $\$ 48,171$ in addition to her party's full spend. In contrast, The Greens' candidate, Adam Stone, was able to muster only an additional $\$ 1,823$ to top up his party's spending. ${ }^{28}$ So while the ratio by which Queensland's minor parties are outspent may have fallen fairly sharply after the introduction of spending caps, in practical terms they were still at a significant financial disadvantage in 2012 compared with the two major parties. ${ }^{29}$

Where these caps do appear to have had more of an impact is in levelling the field between the two major parties. Specifically, the spending caps cancelled out the impact of differing fundraising capacities, because the parties could not spend more than the capped amount regardless of how much they raised. At the 2012 election, the ALP would have been at a significant disadvantage compared with the LNP if the spending caps had not been in place, because the government's predicted loss meant that it failed to attract donations on the same scale as the Opposition. The volume of donations Labor received easily exceeded the new cap, however, and so the party was able to closely match the LNP's spending despite having less money on hand overall. It seems unlikely that this is the kind of levelling proponents of finance caps have in mind when advocating for their introduction, but the Queensland case suggests that this may actually be the most direct effect of such reforms.

\section{Case study 2: New South Wales}

Turning our attention to NSW, the data suggest similar trends and patterns to those seen in Queensland - that is, spending and donation caps go some way towards narrowing the gulf between major and minor party budgets, but do far more to equalise the contest between the two major parties.

\footnotetext{
28 All candidate figures are sourced from original campaign returns submitted to Electoral Commission Queensland, available at: www.ecq.qld.gov.au/candidates-and-parties/fundingand-disclosure/disclosure-returns.

29 Whether or not this disparity is desirable reflects broader debates about different types of party democracy, electoral competition and the appropriate ratio of resources to electoral support.
} 
Figure 6.4 provides a side-by-side comparison of spending for a selection of major and minor parties contesting both Legislative Assembly and Legislative Council elections between 2003 and 2011, while Figures 6.5 and 6.6 provide the details on spending relative to donations.

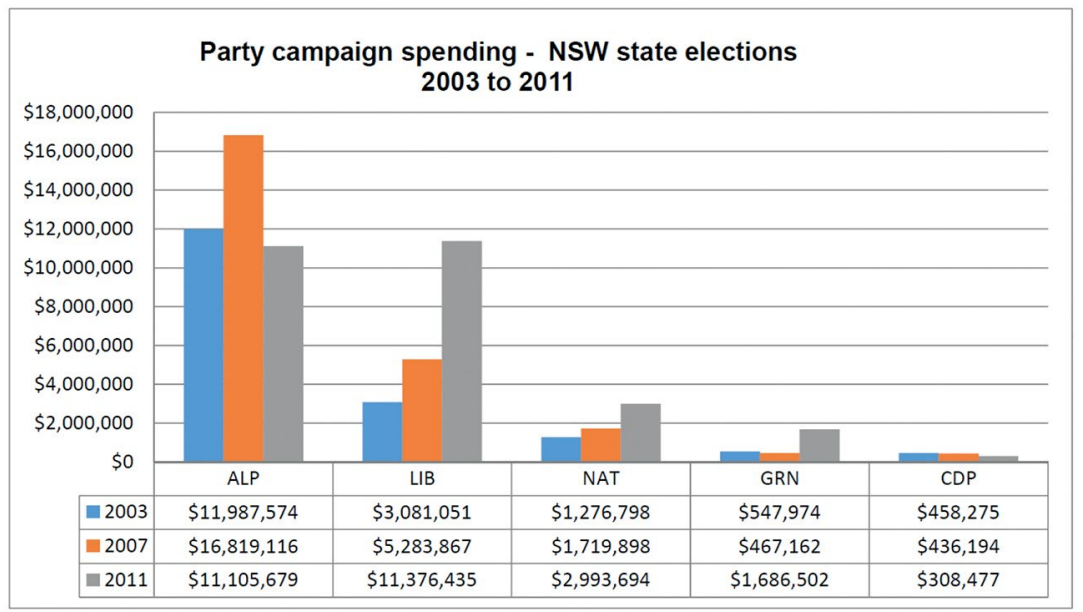

Figure 6.4 NSW campaign spending, 2003-11

Source: All spending figures from the NSW Election Funding Authority.

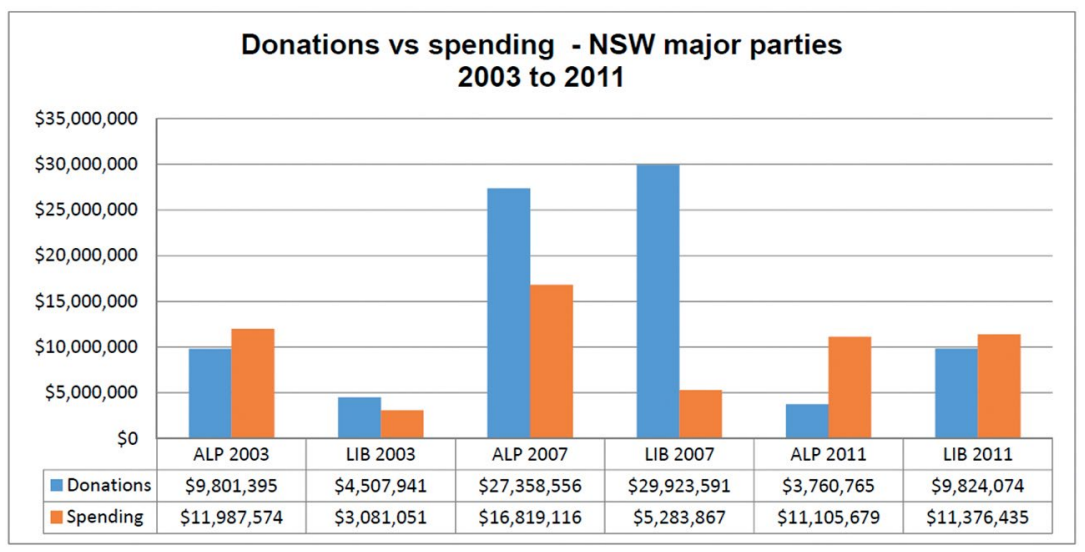

Figure 6.5 NSW major party donations relative to spending, 2003-11

Source: All spending figures from the NSW Election Funding Authority. 


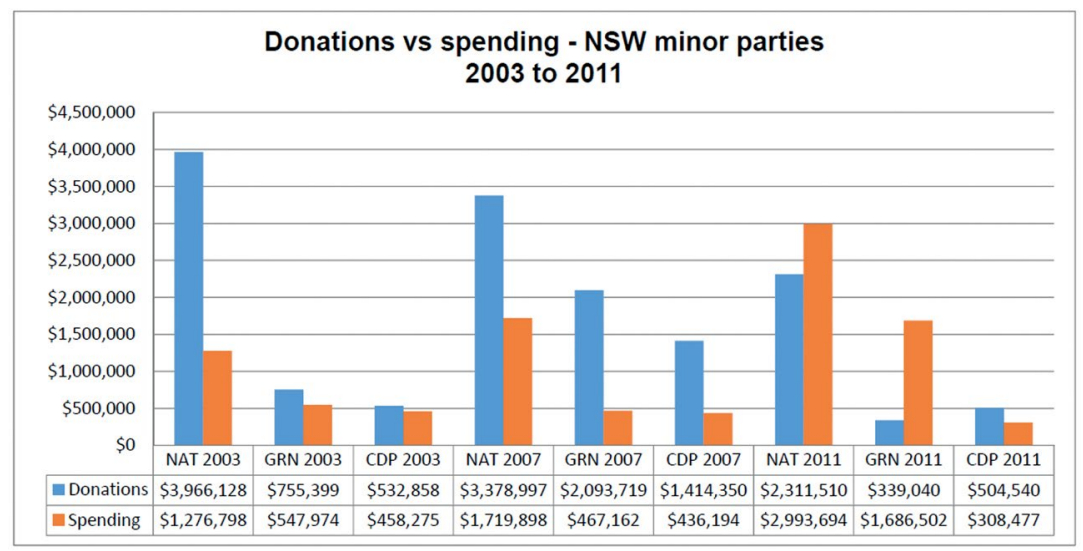

Figure 6.6 NSW minor party donations relative to spending, 2003-11

Source: All spending figures from the NSW Election Funding Authority.

These figures again demonstrate significant variation in party budgets in 2003 and 2007-both among the major parties and between them and the minor ones. The gap in spending between the Labor and Liberal parties is then almost entirely erased in 2011 after the introduction of the caps, but there continues to be a significant gulf between these two parties' budgets and the amounts spent by the three minor parties. This is clearly reflected in Table 6.6, which again highlights the dollar figures earned and spent per enrolled voter in each election year.

Table 6.6 NSW party funds: Dollars per voter

\begin{tabular}{|l|c|c|c|c|c|c|}
\hline & \multicolumn{2}{|c|}{2003} & \multicolumn{2}{c|}{2007} & \multicolumn{2}{c|}{2011} \\
\hline Size of roll & \multicolumn{2}{|c|}{$4,272,104$} & \multicolumn{2}{c|}{$4,374,029$} & \multicolumn{2}{c|}{$4,635,810$} \\
\hline & Received & Spent & Received & Spent & Received & Spent \\
\hline $\begin{array}{l}\text { Australian Labor } \\
\text { Party }\end{array}$ & $\$ 2.29$ & $\$ 2.81$ & $\$ 6.25$ & $\$ 3.85$ & $\$ 0.81$ & $\$ 2.40$ \\
\hline Liberal Party & $\$ 1.05$ & $\$ 0.72$ & $\$ 6.84$ & $\$ 1.21$ & $\$ 2.11$ & $\$ 2.45$ \\
\hline The Nationals & $\$ 0.92$ & $\$ 0.30$ & $\$ 0.77$ & $\$ 0.39$ & $\$ 0.50$ & $\$ 0.65$ \\
\hline The Greens & $\$ 0.18$ & $\$ 0.13$ & $\$ 0.47$ & $\$ 0.11$ & $\$ 0.07$ & $\$ 0.36$ \\
\hline $\begin{array}{l}\text { Christian Democratic } \\
\text { Party }\end{array}$ & $\$ 0.12$ & $\$ 0.11$ & $\$ 0.32$ & $\$ 0.10$ & $\$ 0.11$ & $\$ 0.07$ \\
\hline
\end{tabular}

Source: Figures calculated from spending data from the NSW Election Funding Authority. 
It is interesting to note that for the 2011 election, all parties except the Christian Democratic Party (CDP) spent more than they received in donations - sometimes significantly so. This suggests that: a) the parties had been stockpiling funds from previous years in anticipation of the new finance regime; and b) the prohibition on accepting money from certain categories of donor resulted in a serious hit to party fundraising capacities, particularly for the major parties. ${ }^{30}$ Having said that, it is not possible to make a direct comparison between the donations received in 2007 and those in 2011 because the former was also a federal election year, so donations to all parties dramatically exceeded their spending on the NSW campaign.

Table 6.6 shows that, as in Queensland, in NSW there were major differences in the amounts spent and received per voter between major and minor parties - both before and after the introduction of the caps. However, the picture becomes more complicated if we consider the ratios of funding, as detailed in Table 6.7. In this instance, we have opted to compare 2003 and 2011, because of the donations anomaly in 2007.

Table 6.7 Ratios of major and minor party finances: NSW*

\begin{tabular}{|l|c|c|c|c|c|c|c|c|}
\hline & \multicolumn{4}{|c|}{2003} & \multicolumn{3}{c|}{2011} \\
\hline & \multicolumn{2}{|c|}{ Donations } & \multicolumn{2}{c|}{ Spending } & Donations & \multicolumn{2}{c|}{ Spending } \\
\hline & ALP & LIB & ALP & LIB & ALP & LIB & ALP & LIB \\
\hline The Nationals & $2: 1$ & $1.2: 1$ & $9: 1$ & $3: 1$ & $2: 1$ & $4: 1$ & $4: 1$ & $4: 1$ \\
\hline The Greens & $13: 1$ & $6: 1$ & $22: 1$ & $6: 1$ & $11: 1$ & $29: 1$ & $7: 1$ & $7: 1$ \\
\hline $\begin{array}{l}\text { Christian } \\
\text { Democratic Party }\end{array}$ & $18: 1$ & $8: 1$ & $26: 1$ & $7: 1$ & $7: 1$ & $19: 1$ & $36: 1$ & $36: 1$ \\
\hline
\end{tabular}

* Ratio of dollars received and spent by the major parties relative to every dollar of minor party funding (all minor parties aggregated).

Source: Calculated from spending and donations data from the NSW Election Funding Authority.

Table 6.7 indicates that the financial gap between major and minor parties in NSW was already significantly smaller than that in Queensland before the introduction of caps. In fact, the ratio of major to minor party finances in NSW before the caps were introduced was

30 Of course, given the details emerging from the Independent Commission Against Corruption's ongoing inquiries, it is possible further donations were simply channelled through other avenues that were not declared to the Election Funding Authority. 
lower than comparable ratios achieved in Queensland after regulatory reform. This suggests that NSW minor parties were playing on a more even field than their Queensland counterparts even before legislative attempts to level this. Interestingly, Table 6.7 also shows that after the introduction of the NSW caps, the minor party ratios became more varied in comparison with those for the major parties. The general trend appears to be that the financial gap between the ALP and the minor parties shrank, while it increased for the Liberal Party. However, it is difficult to determine how much of this is due to the impact of the caps and how much relates to the variable patterns of party spending at the previous elections. Further data will be needed from the 2015 election and beyond to definitively address this point.

In terms of assessing the effectiveness of the NSW caps, the data presented here are somewhat more ambiguous about their impact than is the case for Queensland. As in that State, in NSW it seems clear that major parties raised and spent substantially more money than their minor counterparts before the spending and donations caps were introduced, and continued to do so after they were put in place. Also in common with Queensland, in NSW the most significant narrowing of financial gaps took place between the two major parties, as the difference in their campaign budgets shifted from millions of dollars to just a few hundred thousand. There continued to be a significant gulf in the volume of donations received by these two parties, although in 2011 the Liberals had the upper hand rather than Labor. This reversal probably has more to do with the political environment than the caps themselves, although, again, further data will be needed to confirm this.

While this analysis suggests that donation and spending caps do not provide a substantial benefit to minor parties at a Statewide level, NSW offers one case that suggests that they may do so at the individual electorate level. For example, at the 2011 election, the seat of Balmain was among the most high profile, as Labor Minister Verity Firth was challenged by popular local Greens Mayor, Jamie Parker. The NSW Greens had never previously managed to place a member into the State's Legislative Assembly, but were ultimately successful in doing so in Balmain after Parker secured 50.1 per cent of the vote on preferences. In an interview conducted after the election, Parker suggested that the caps were a significant factor in the result, because they prevented him from being 'smashed financially' by Firth 
and the ALP. ${ }^{31}$ Both parties reportedly spent the maximum amount allowed in central spending and the individual candidate returns show that Parker then spent $\$ 79,337$ from his personal cap while Firth spent $\$ 100,281 .^{32}$ Parker reflected that in previous elections in which he had been involved, the ALP had been able to deluge electorates in direct mail, television advertising and other campaign materials when the result was expected to be closely run. In 2011, however, the spending cap prevented Firth and Labor from spending more than $\$ 150,000$ to hold on to the seat, so The Greens were able to come within $\$ 20,000$ of matching their spending. ${ }^{33}$ Importantly, however, this would not have been the case if Parker had struggled to raise additional funds for his individual spending, as was generally the case with The Greens candidates in Queensland. The fact that he was able to raise almost $\$ 80,000$ may reflect his impressive personal characteristics or it may simply have been a result of the strong anti-Labor sentiment then prevalent in NSW. However, in 2015- a State election characterised by an arguably less volatile political environment-Parker retained the seat of Balmain, polling 37 per cent of the primary vote to Firth's 31 per cent share.

While it is impossible to draw any conclusions about the broader effectiveness of caps from this single instance, the Balmain experience suggests that it would be worth looking at competition in individual electorates to gain further insights into how far these go towards creating a level playing field between major and minor parties. This would be a much larger research undertaking than examining party spending, as it would involve analysing the individual returns for every candidate contesting each State seat over a series of elections. For that reason, I have not included such analysis here; the contribution is simply to highlight the Balmain case as one that may point to a trend worth exploring through future research.

\footnotetext{
31 Author interview.

32 All candidate figures sourced from original campaign returns submitted to the NSW Election Funding Authority, available at: elections.nsw.gov.au/fd/disclosure/view_disclosures.

33 Author interview.
} 


\section{Conclusion: Do spending and donation caps help to level the field?}

In light of the above discussion about patterns in party financing before and after the introduction of tighter regulations in Queensland and NSW, could we say that spending and donation caps help to create a more level electoral playing field in terms of equalising the amount of money political parties are able to raise and spend?

The answer would appear to be a resounding 'yes', if we specifically consider competition between the two major parties. Both the Queensland and the NSW cases suggest that capping spending effectively levelled past differences between Labor and the Liberals/ LNP by cancelling out the impact of their divergent fundraising capacities. Because neither party could spend more than a fixed amount, the past advantage enjoyed by the party receiving more donations was effectively erased. This was particularly evident in Queensland, where the LNP managed to raise over \$16 million in spite of the donation caps, but was unable to put this bounty to work because of the $\$ 7.1$ million total spending cap. This suggests that in terms of levelling the playing field, it is the spending side that matters far more than capping donations.

If we consider competition between the major and minor parties, however, the answer changes from an emphatic 'yes' to a more pessimistic 'not really'. On the donations side, the introduction of caps seems to have done little to reduce the incredibly high ratio of major party dollars received compared with minor party ones and, in a number of cases, this actually increased after the caps were put in place. On the expenditure side, there was a marked reduction in the ratio of major party to minor party dollars spent in Queensland, but no clear pattern was apparent in NSW. Furthermore, the dollar-pervoter figures provided in Tables 6.4 and 6.6 clearly demonstrate that even where the ratio of spending has shrunk, the vast differences in the dollar figures involved mean that minor parties remain at a serious and stark disadvantage. Given that caps do appear to restrain major party spending to the maximum amount allowed by the regulatory scheme, this issue could be addressed by significantly lowering the value of the caps. For example, at the 2014 New Zealand national 
election parties were subject to a total cap of just under $\$ 3$ million while individual candidate spending was capped at just $\$ 25,700,{ }^{34}$ so there is some international precedent for setting the bar much lower than is currently the case in the two Australian schemes. However, given that the caps are set by parliaments that are dominated by the two major parties, it seems unlikely that we would ever see them drop these so low as to truly equalise the contest for their minor party competitors.

Finally, if we consider the case of Balmain, this suggests that spending and donation caps possibly do 'a bit' to equalise competition between major parties and those in the second tier of party wealth in specific electorates. By preventing major parties from bringing their superior resources to bear in any single seat, the spending caps may prevent the voices of minor party candidates from being drowned out, and therefore increase their chances of election. Importantly, however, the comparison between The Greens' experiences in Queensland and in NSW suggests that candidates need to be able to match their major party counterparts' individual spending as well as matching them in the party spending to secure any meaningful advantage. By logical extension, this would seem to mean that only 'major minor' parties such as The Greens or The Nationals are likely to benefit from this levelling, as it seems highly unlikely that any of the 'minor minor' parties in the third tier of wealth would be able to scale such a financial obstacle.

Overall, then, the financial cap schemes examined in Queensland and NSW do not appear to create the kind of level field on which proponents of a federal scheme might wish to play. Having said that, there are many good reasons why caps may still be beneficial, including limiting opportunities for outside groups to influence political outcomes through large donations; reducing the volume of advertising and promotional clutter associated with elections; and freeing up parties to focus more of their time on policy development and community engagement rather than fundraising. In all of these areas, there may well be a case to be made for the effectiveness of spending and donation caps. However, this discussion has specifically

34 New Zealand Electoral Act 1993, Part 6A, s. 205C and s. 206C. 
focused on whether increased financial regulation can make electoral competition - in terms of the money parties raise and spendmore even. The evidence presented here from two recent Australian case studies is by no means definitive, but does suggest that in the form in which they have been applied to date, spending and donation caps do little to level out Australia's skewed political pitch. 
This text is taken from Party Rules?: Dilemmas of political party regulation in Australia, edited by Anika Gauja and Marian Sawer, published 2016 by ANU Press, The Australian National University,

Canberra, Australia. 